\title{
Volatile organic compound profiling of Capsicum annuum var. longum grown under different concentrations of nitrogen
}

\author{
Y.C. David', J.B. Ylagan', H.A. Gonzales', J.M.P. Chan', J.M.S. Mondragon', \\ M.A.A. Tavera ${ }^{1,2}$ and M.C.F.R. Redillas ${ }^{1 *}$
}

Summary Emission of volatile organic compounds (VOCs) in plants is triggered by several biotic and abiotic factors, such as nutrient deficiency, environmental stress, and pathogenic attacks. For instance, plants suffering from limited or excessive nitrogen $(\mathrm{N})$ supply may experience internal stress which can ultimately lower their stability and immunity making them susceptible to infection and infestation. In this study, VOCs from Capsicum annuum var. longum (Solanaceae) exposed to nitrogen (1.8 g/L, 4.5 $\mathrm{g} / \mathrm{L}$, and $9 \mathrm{~g} / \mathrm{L}$ urea) were extracted using a $100 \mu \mathrm{m}$ Solid Phase Microextraction (SPME) fiber coated with polydimethylsiloxane (PDMS). Using Gas Chromatography-Mass Spectrometry (GC-MS), extracted VOCs from N-treated plants were identified as Butanoic acid, 3-hexenyl ester, (E)-; Butanoic acid, hexyl ester; Hexanoic acid, 3-hexenyl ester, (Z)-; Hexanoic acid, 4-hexen-1-yl ester; cis-3-Hexenyl cis-3-hexenoate and 4-Pentenoic acid 2-methyl-, hexyl ester. Among these volatiles, butanoic acid, 3-hexenyl ester showed the most distinctive peak from the $\mathrm{N}$-treated plants in comparison with the untreated. In addition, the Green Leaf Volatiles (GLV) 3-Hexenal; 2-Hexenal; 3-Hexen-1-ol, (Z)-; 2-Hexen-1-ol, (E) and 1 -Hexanol were also detected from the N-treated plants. The identification of plant volatiles provides useful information that can be used in agricultural practices and plant phenotyping.

Additional keywords: Butanoic acid, GC-MS, Green Leaf Volatiles, Polydimethylsiloxane, Solid Phase Microextraction Fiber

\section{Introduction}

The Capsicum genus (Solanaceae) represents a diverse plant group where varieties have been produced from different climatic conditions and cultivation periods (Gaytan et al., 2017). Among the 20-27 identified species (Walsh and Hoot, 2001), Capsicum chinense, Capsicum frutescens, Capsicum annuum, Capsicum baccatum, and Capsicum pubescens are globally cultivated (Heiser and Pickersgill, 1969). Among these five reared capsicums, $C$. annuum is the most extensively cultivated across the globe. Varieties of C. annuum are further categorized

\footnotetext{
1 Department of Biology, De La Salle University, 2401 Taft Ave, Malate, Manila, 0922 Metro Manila, Philippines.

2 Biological Control Research Unit, Center for Natural Sciences and Environmental Research, De La Salle University, 2401 Taft Ave, Malate, Manila, 0922 Metro Manila, Philippines.

* Corresponding author: mark.christian.redillas@dlsu. edu.ph
}

based on its fruit shape, namely, C. annuum var glabriusculum, $C$. annuum var abbreviatum, $C$. annuum var grossum, $C$. annuum var anuum and C. annuum var accuminatum (Zhigila et al., 2014). C. annuum generally grows in areas with subtropical to tropical climate where there is a temperature and an annual rainfall range of $20-25^{\circ} \mathrm{C}$ and $120-850$ $\mathrm{mm}$, respectively. C. annuum var. longum, commonly known as Green long chili or "siling haba", originated from tropical America and has been widely cultivated in the Philippines for food purposes, predominantly used as a spice and for seasoning, and medicinal uses (McBride, 2016). Capsicum usually requires four to five months before it reaches complete growth (Bargavi and Elumalai, 2010) while yield is also significantly affected by nutrient availability (Anitha and Geethakumari, 2006). Some of the key factors affecting the growth and productivity of capsicums are pests, diseases, temperature, soil characteristics, and water availability (Bhutia et al., 2018). The tillage, irriga- 
tion, spacing, and sowing strategies can also have an impact on the development of capsicums (Sharma and Kumar, 2017; Islam et al., 2011).

Nitrogen, one of the essential nutrients in plant productivity, is usually supplied as fertilizer given directly to the soil or blended with the irrigation water. Upon contact with soil, N-fertilizers, such as urea, begin to breakdown and hydrolyze into ammonium and carbon dioxide. Although the addition of urea can increase dry weight and enhance drought tolerance of plants (Gou et al., 2017), their response to the availability of nitrogen varies in plant species, cultivars, plant organs, and tissues (Effan et al., 2019; Moreau et al., 2015). This variation can be attributed to the plants' efficiency to absorb nitrogen and carbon, which can be measured as radiation use efficiency, root weight ratio, nitrogen uptake efficiency, and morphogenic efficiency (Moreau et al., 2015).

In C. annuum, the introduction of nitrogen is reported to have led to an increased pod number (83.47\%), seed number (19.27\%), plant height (42.7\%), branch number (37.7\%) and leaf number (63.5\%) (Molla et al., 2019). High accumulation of nitrogen can trigger the release of growth hormone factors such as cytokines and gibberellins resulting in an increased plant height. The phenological properties, such as flowering, maturity, and pod settings of hot pepper plants are also affected by nitrogen (Molla et al., 2019). The addition of appropriate $\mathrm{N}$ concentration could improve production yield in C. annuum, however, excessive nitrogen may damage its reproductive structures (Aliyah, 2000). Besides, differences in available nitrogen levels significantly affect plant VOC production (Holopainen and Gershenzon, 2010) while deficiency alters VOC emission (Lou and Baldwin, 2004). For instance, tomato plants exposed at high nitrogen concentration were able to produce various terpenes, such as $\beta$-caryophyllene, a-terpinene, $\beta$-pinene, (+)-4-carene, a-copaene, $p$-cymene, $\beta$-phellandrene, and $\alpha$-humulene (Islam et al., 2017).

Approximately 1,700 of the 100,000 phy- tochemicals are classified as volatile organic compounds (VOCs) (Holopainen and Gershenzon, 2010; Spinelli et al., 2011). As plants remain the top VOC emitter, its annual emission reaches around $760 \mathrm{Tg}\left({ }^{\circ} \mathrm{C}\right)$ across the globe (Samburova et al., 2019). Its crucial role in plants can be attributed to the plant-plant and plant-biota interaction to act as a defense mechanism against invasive insects, alleviation of environmental stress, and signal between and within plants (Spinelli et al., 2011). These volatile emissions could be traced from the bursting of plant organs with stored VOCs due to herbivory or de novo synthesis as a response to damaged organs (Holopainen and Gershenzon, 2010). In some cases, VOCs are released by carnivorous plants to attract their prey (Kreuzwieser et al., 2014). Some of the most common VOCs identified from plants include isoprene, monoterpenes, and sesquiterpenes (Samburova et al., 2019). Its emission can greatly vary depending on the plant species, type of organ, stage of development, and ecological conditions (Jassbi et al., 2010).

The main classes of VOCs previously identified from different species of capsicums belong to aliphatic branched-chain hydrocarbons, terpenes, aldehydes, and alcohols (Ziino et al., 2009). Previous studies also identified the different VOCs that are naturally produced in chilli pepper plants. For instance, a total of 64 plant volatiles identified as terpenes and its derivatives, pyrazines, alcohols, aldehydes, ketones, esters, hydrocarbons, and carotenoid derivatives were detected from powdered chilli pepper fruits using HS-SPME/GC-MS method (Cirlini et al., 2019). These VOCs, in combination with nonVOCs are often associated with the fruit's flavor and aroma giving it its unique taste and smell (Eggink et al., 2012a, 2012b; Cirlini et al., 2019). Similarly, a variety of VOCs were also detected from chili pepper seeds (Silva et al., 2013). From these studies, only few reported the influence of elevated nitrogen concentrations on the profile of VOCs in capsicums. Therefore, this study aims to determine the effects of nitrogen nutrition on the VOCs profile of $C$. annuum var. longum. 


\section{Materials and Methods}

\section{Plant cultivation, nitrogen treatment,} and sample collection

Forty-five-day old seedlings of C. annuum var. longum were acquired from the Bureau of Plants Industry, Manila, Philippines. Plants were allowed to grow for 4 weeks in a nursery at De La Salle University, Manila for the experimental process. Plants received similar treatments such as watering and occasional rotation to attain uniform treatments. For nitrogen $(\mathrm{N})$ treatments, urea was used as $\mathrm{N}$ source. Three concentrations were prepared by dissolving $1.8 \mathrm{~g}(1 \mathrm{x}), 4.8 \mathrm{~g}$ (2.5x) and $9 \mathrm{~g}(5 \mathrm{x})$ of urea in $1 \mathrm{~L}$ distilled water. The $\mathrm{N}$-treatment started when $500 \mathrm{~mL}$ of $\mathrm{N}$ solutions were introduced to the soil. Untreated plants were given the same amount of water (0x). Control and treated C. annuum var. longum leaves were collected after 4 weeks. All treatments were conducted in triplicates.

\section{Volatile organic compound analysis}

From each plant, a total of three leaves were collected from the top, middle, and bottom parts of the plant. Then, samples were acclimatized for 1 hour before the analysis. Collected leaf samples were placed in a $500 \mathrm{~mL}$ Pyrex ${ }^{\circledR}$ Erlenmeyer flask sealed with parafilm and covered with aluminum foil. The flask served as a headspace chamber for VOC analysis (Tavera et al., 2018). Volatile organic compounds were extracted using a Supelco ${ }^{\circledR} 100 \mu \mathrm{m}$ Polydimethysiloxane Solid Phase Microextraction fiber (SPME). PDMS fiber was selected in this study to include both low and high molecular mass volatile compounds in addition to the short desorption time and thermal stability of the fiber as reported by the group of Perera et al. (2020). Initially, the fibers were conditioned at $250^{\circ} \mathrm{C}$ for $30 \mathrm{~min}$ to remove chemical residues. The flasks containing the samples and the fiber were heated at $30^{\circ} \mathrm{C}-40^{\circ} \mathrm{C}$ for 15 min to initiate the release of VOCs (Silva et al. 2017). While the samples were heating, the fiber was exposed inside the flask to collect VOCs from the headspace. For the control, the SPME fibers were exposed to flask without the leaf samples (Tavera et al., 2018).

\section{Gas Chromatography-Mass Spectrometry}

The analysis of VOCs was performed using Gas Chromatography-Mass Spectrometry (Shimadzu GC-MS QP2020) equipped with SH-Rxi-5Sil MS capillary column $(30 \mathrm{~m}$ $\times 0.25 \mathrm{~mm} \times 0.25 \mu \mathrm{m}$ ). The samples were passed through a pre-installed SPME Inlet liner and Merlin Microseal Septa General Purpose Kit. The injection temperature was set to $250^{\circ} \mathrm{C}$ with an initial temperature of $50^{\circ} \mathrm{C}$ for 5 minutes and a ramping temperature of $1^{\circ} \mathrm{C}$ per minute until it reached $200^{\circ} \mathrm{C}$ with a constant helium gas flow rate of $1 \mathrm{~mL} /$ min. The mass spectra of the $\mathrm{N}$ treated samples were compared with the control and the distinct VOC mass spectra found were identified using the NIST 2017 Mass Spectral Library and Wiley Registry $11^{\text {th }}$ edition (Tavera et al., 2018).

\section{Results}

The effect of high N-supply on the VOC profile of $C$. annuum var. longum is presented in Figure 1. After the four-day treatment, the plants which received urea higher than 1.8 $\mathrm{g} / \mathrm{L}$ concentration started to exhibit curling and wrinkling of leaves. The plants treated with $5 \times \mathrm{N}$ dried up within $48 \mathrm{~h}$ and were not included for further analysis. This type of response is typical in plants when urea is suddenly introduced. N-treated plants also developed black spots on the leaves which may be caused by a weakened innate defense system or $\mathrm{N}$ toxicity. Furthermore, aphids and whiteflies appeared on the $\mathrm{N}$ treated plants four days after treatment. On the other hand, the untreated control plants showed normal growth and absence of insects, suggesting that the $\mathrm{N}$ supply may have caused the observed responses and the attraction of insects to $\mathrm{N}$-treated plants. The sensitivity of $C$. annuum var. longum to $\mathrm{N}$-treatment further suggests that this species is a very good candidate for $\mathrm{N}$-stress studies. 

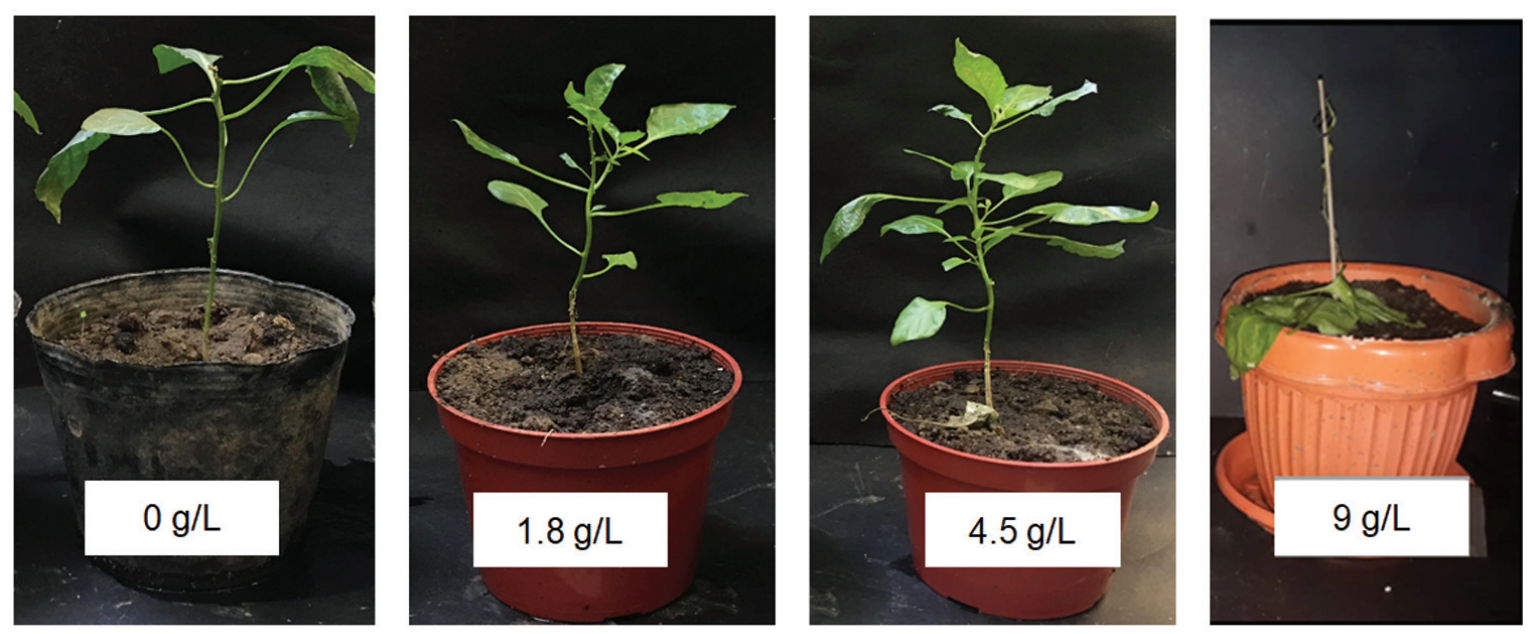

Figure 1. Representatives of C. annuum var. Iongum treated with $0 \mathrm{~g} / \mathrm{L}, 1.8 \mathrm{~g} / \mathrm{L}, 4.5 \mathrm{~g} / \mathrm{L}$ and $9 \mathrm{~g} / \mathrm{L}$ Urea after $48 \mathrm{~h}$ supply.

The VOCs collected from the leaves of $\mathrm{N}$ treated setups ( $1 \mathrm{x}$ and $2.5 \mathrm{x}$ ) and compared to those of the control (0x) are shown in Figure 2A-F. In general, the VOCs common in N-treated and untreated C. annuum var. longum belonged to the group of alkanes, sesquiterpenes, carboxylic acids, aldehydes, ketones, alcohols, and alkenes. Among these plant volatiles, Butanoic acid, 3-hexenyl ester [peak \#6], (E)-, Butanoic acid, hexyl ester [peak \#7], Hexanoic acid, 3-hexenyl ester, (Z)- [peak \#8], Hexanoic acid, 4-hexen-1-yl ester [peak \#9], cis-3-Hexenyl cis-3hexenoate [peak \#10], and 4-Pentenoic acid
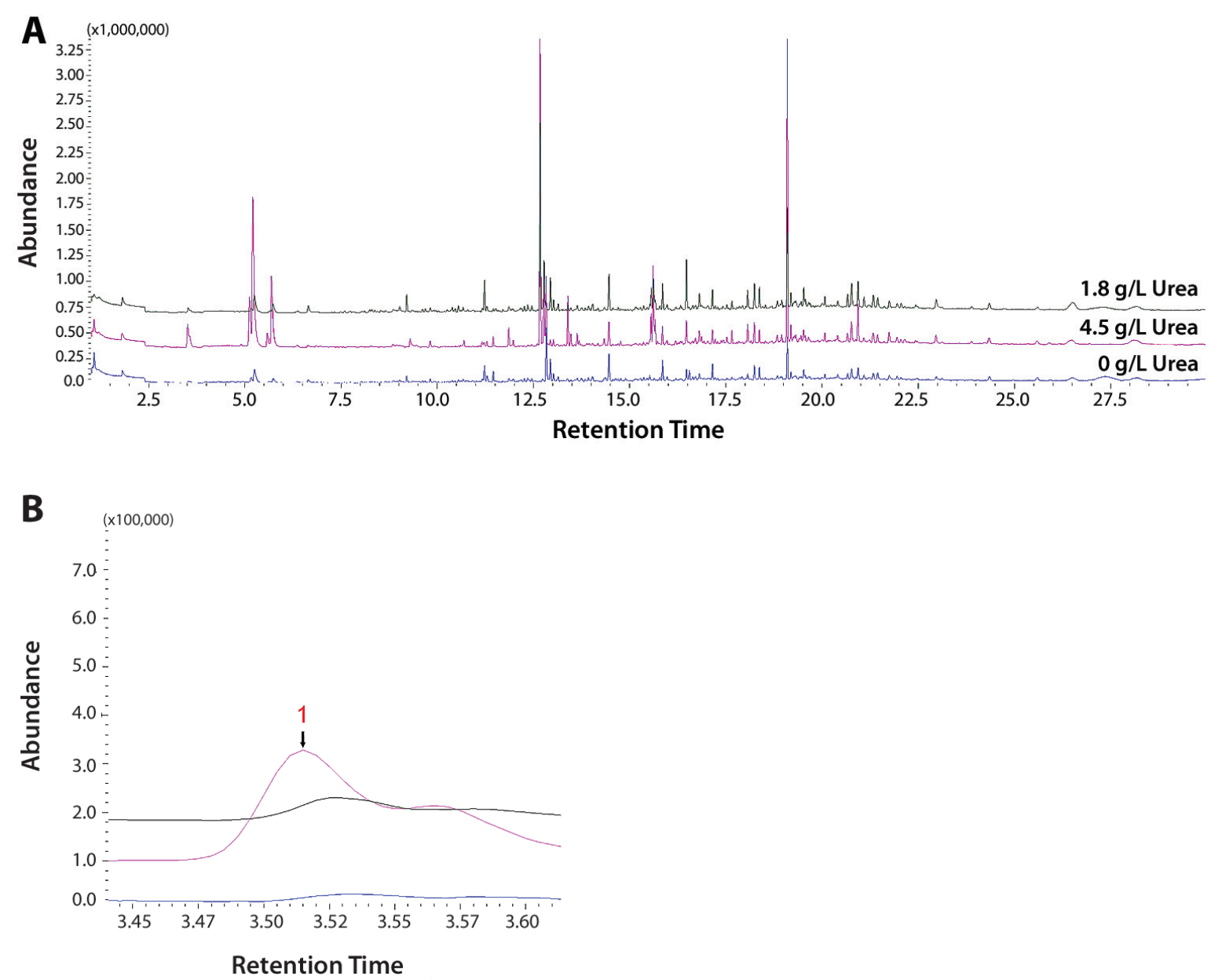

(c) Benaki Phytopathological Institute 


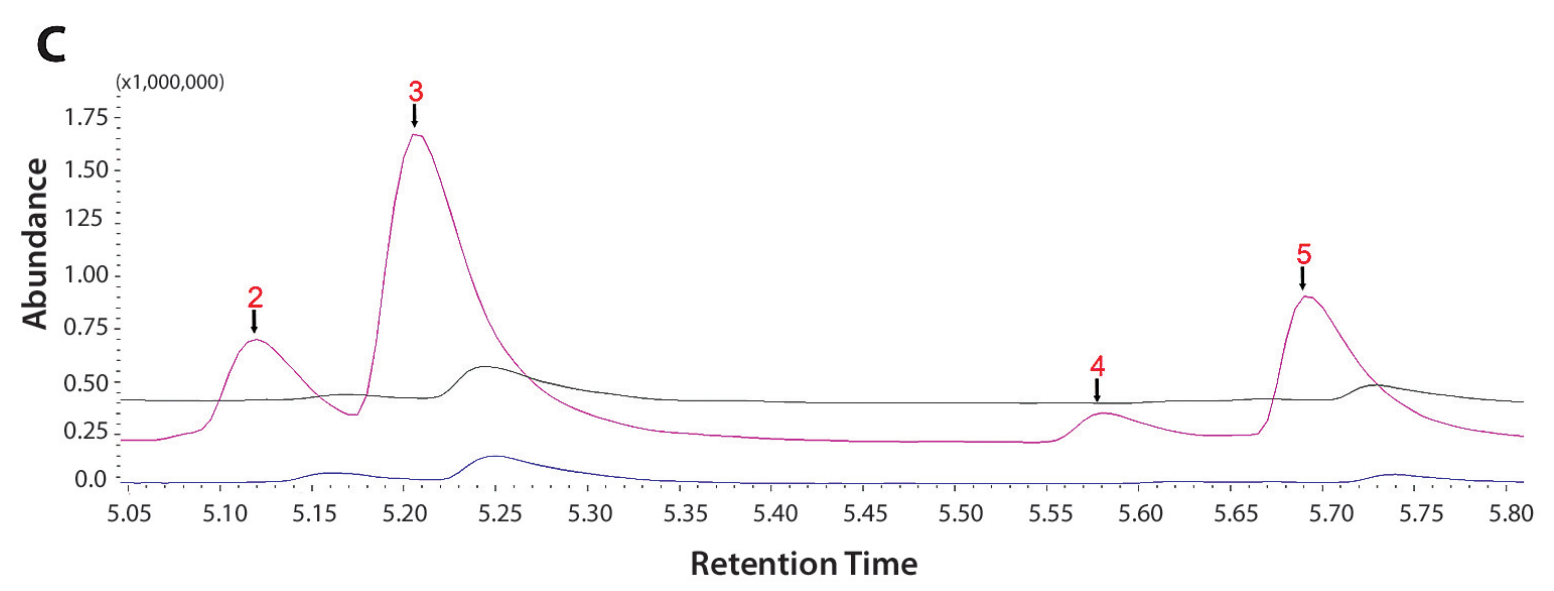

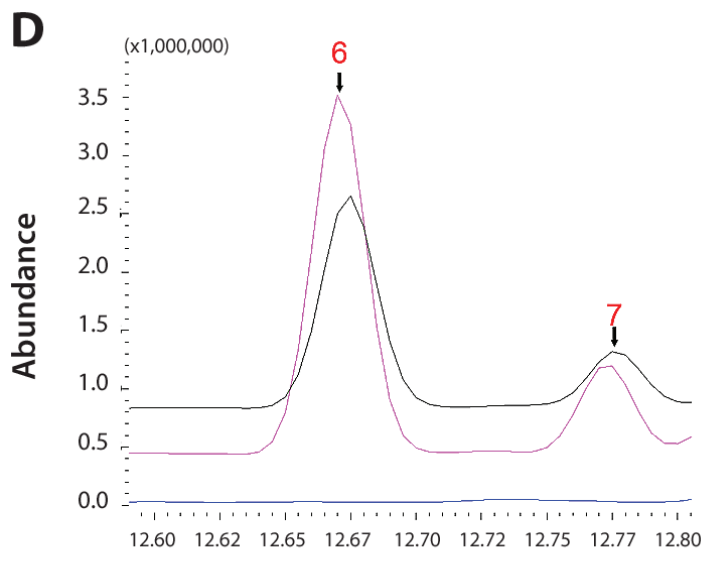

Retention Time

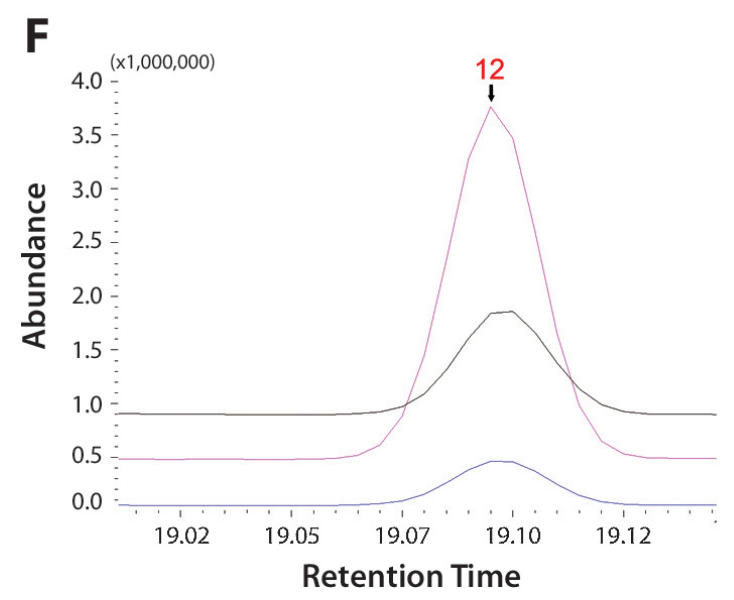

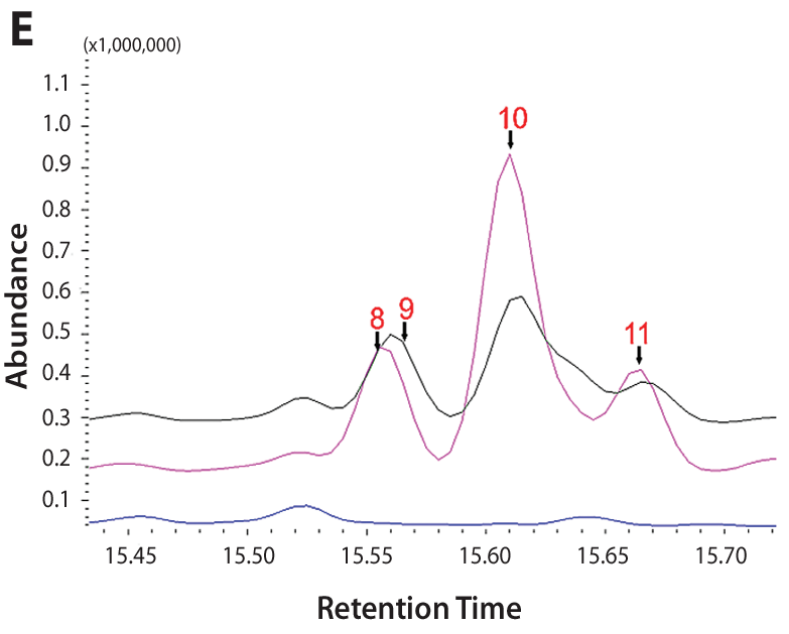

Figure 2. (A) GC-MS analysis of the volatile organic compounds identified from C. annuum var. longum. Magnified version of the chromatograms with retention times are shown in (B) $3.40-3.60$ (C) $5.05-5.80$ (D) $12.60-12.80$ (E) $15.45-15.70$ (F) 19.02 - 19.12. The detected compounds were 3-Hexenal [1, 3.527], 2-Hexenal [2, 5.120], 3-Hexen-1-0l, (Z)- [3, 5.207] and 2-Hexen-1-0l, (E)- [4, 5.581], 1-Hexanol [5, 5.692], Butanoic acid, 3-hexenyl ester [6, 12.776], (E)-, Butanoic acid, hexyl ester [7, 12.674], Hexanoic acid, 3-hexenyl ester, (Z)- [8, 15.557], Hexanoic acid, 4-hexen-1-yl ester [9, 15.561], cis-3-Hexenyl cis3-hexenoate [10, 15.61315], and 4-Pentenoic acid 2-methyl-, hexyl ester [11, 15.666] and 0ctane, 1,1'-oxybis- [12, 19.096]. Samples for 1x, 2.5x and control are shown as black, purple and blue lines, respectively. 
2-methyl-, hexyl ester [peak \#11] were the ones detected from $\mathrm{N}$-treated plants.

Other plant volatiles, such as 3-Hexenal [peak \#1], 2-Hexenal [peak \#2], 3-Hexen1-ol, (Z)- [peak \#3], 2-Hexen-1-ol, (E)- [peak \#4] and 1-Hexanol [peak \#5], which are part of the green leaf volatile synthesis were detected as shown in peak areas on the GC-MS analysis (Fig. 2A-F). The matching factor and structure of the plant volatiles are shown in Table 1. Among these volatiles, only 2-hexenal, 3-Hexen-1-ol, (Z)- and 1-Hexanol were identified from the control samples. The 3-Hexen-1-ol, (Z)- and 1-Hexanol identified from the treated samples have increased peak areas, whereas 2-hexenal only increased in plants treated with $2.5 \mathrm{x}$ urea. On the other hand, 3-hexenal was identified only from plants treated with $1 \mathrm{x}$ and 2.5x urea, whereas 2-Hexen-1-ol, (E)- was only identified in plants treated with $2.5 \mathrm{x}$ urea. Also, the peak area of Octane, 1,1'-oxybis- [peak \#12] increased as $\mathrm{N}$ concentration increased. These results suggest that the VOCs detected were in response to the increased concentration of $\mathrm{N}$. The characteristics of each VOCs, including the retention time, matching factor, and structure can be found in Table 1.

\section{Discussion}

In general, plants respond to changes in the concentration of exogenous nitrogen (N) present in soil from molecular up to the physiological level. These changes elicit an appropriate response that may benefit or harm the plants (Redillas et al., 2011; Wahocho et al., 2016; Jansson et al., 1986; Jauset et al., 1998; Lu et al., 2007; Veromann et al., 2013; Islam et al., 2017). The application of nitrogen in chili plants in an appropriate amount can affect the production of carbohydrates, protein, ash contents, fibers, fats, and nutrients. An increased nitrogen level (up to 250 $\mathrm{Kg} / \mathrm{ha}$ Urea) in the cultivation of capsicum can improve the plant's height, number of branches, number of days before flowering, and length of fruits (Wahocho et al., 2016).
However, improper application of nitrogen may trigger negative effects on the plants. For instance, increased $\mathrm{N}$ in plants could increase the population of insects which often leads to insect infestation and herbivory (Jansson et al., 1986; Jauset et al., 1998; Lu et al., 2007; Veromann et al., 2013; Islam et al., 2017). In our study, we observed that whiteflies and aphids became attracted to chili plants when treated with $\mathrm{N}$. The silverleaf whitefly (Bemisia tabaci) is one of the most common insect pests in chili plants. It serves as a vector to transmit Begomovirus which can hamper the growth and development of the plant (Firdaus et al., 2011; Salas et al., 2015; Saad et al., 2015). Similarly, the green peach aphid (Myzus persicae) and the cotton aphid (Aphis gossypii) have been reported as pests and viral vectors in Chili plants (Talaga-Taquinas et al., 2020). This attraction of insects to plants with higher nitrogen content has also been documented in other plants, such as potato and tomato plants (Jansson et al., 1986; Jauset et al., 1998; Islam et al., 2017; Veromann et al., 2013). In tomato plants, the greenhouse whitefly (Trialeurodes vaporarium) has shown a high preference for plants with higher $\mathrm{N}$ content for egg-laying and oviposition compared to plants with lower $\mathrm{N}$ content (Jauset et al., 1998). Green peach aphids infestation has also been detected in potato plants with high $\mathrm{N}$ content (Jansson et al., 1986). Similarly, pollen beetles and cabbage seed weevils became more attracted to oilseed rape plants when high $\mathrm{N}$ concentration was introduced to the plant (Veromann et al., 2013).

The emergence of black spots on chili plants treated with $2.5 \mathrm{x} \mathrm{N}$ has also been reported in case of oilseed rape plants exposed to high nitrogen concentration (Veromann et al., 2013). The appearance of black spots may have been due to either a weakened innate defense system or $\mathrm{N}$ toxicity. However, further studies are required to confirm the cause of the emergence of these black spots on N-treated chili plants.

It is widely known that plants release VOCs as a response to abiotic stresses, to reduce their negative impact, and trigger 
Table 1. Plant volatile organic compounds identified from C. annum var. longum treated with $1 \mathrm{x}$ and $2.5 \mathrm{x}$ urea. The retention time, matching factor and structure of the VOCs are shown in the figure.

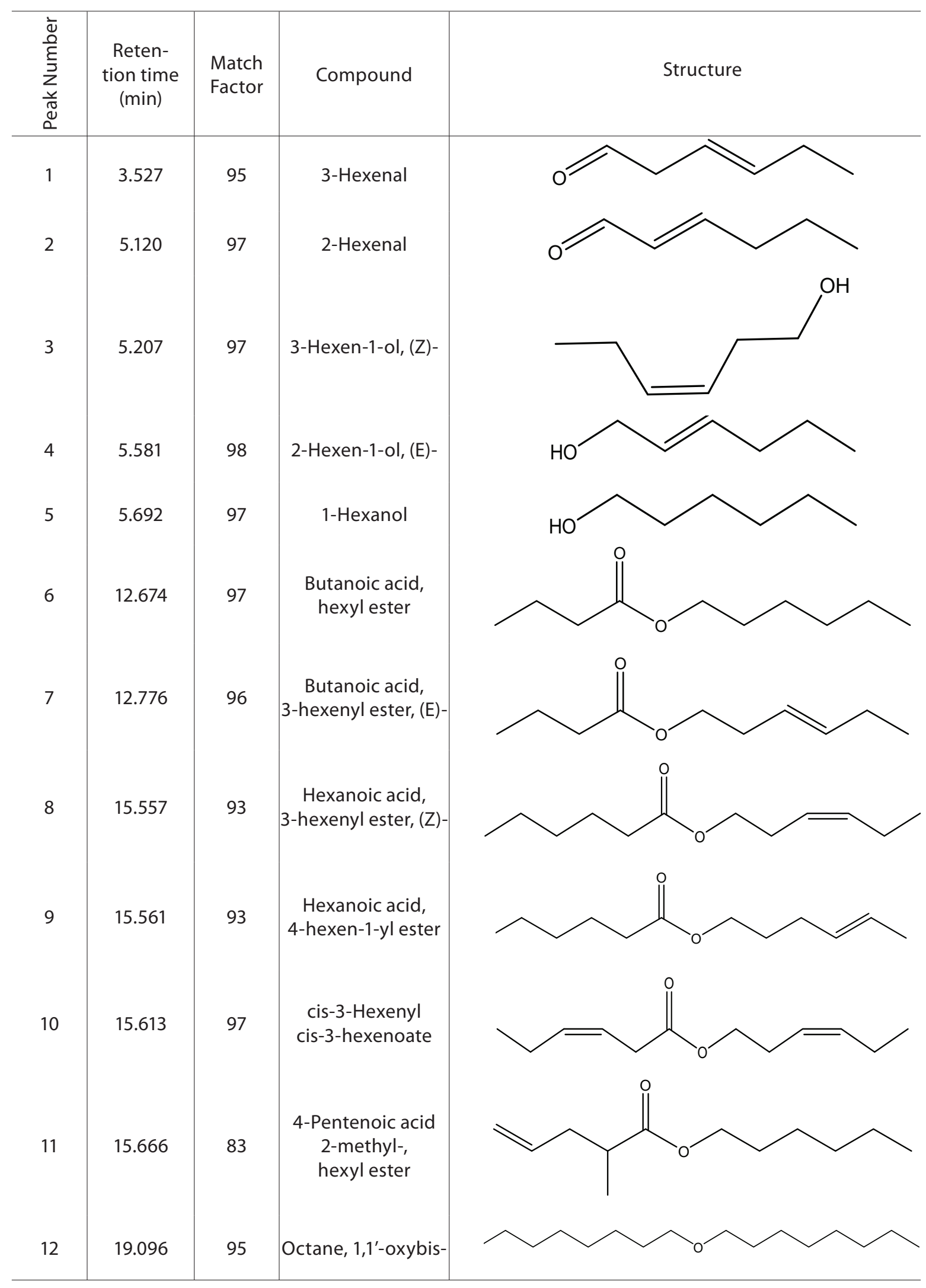


plant-to-plant interactions i.e. water stress (Salerno et al., 2017), drought stress (Hansen and Seufert, 1999), salt stress (Teuber et al., 2008), oxidative stress (Vuorinen et al., 2004), increased temperature (Maleknia et al., 2009), light intensity (Hansen and Seufert, 2003), mechanical damage (Kirstine and Galbally, 1998; 2004), and nutrient deficiency (Gouinguene and Turlings, 2002). A range of plant volatiles has been identified in this study that may function in defense against a wide array of stresses i.e. Butanoic acid, 3-hexenyl ester, (E)-; Butanoic acid, hexyl ester; Hexanoic acid, 3-hexenyl ester, (Z)-; Hexanoic acid, 4-hexen-1-yl ester; cis-3-Hexenyl cis-3-hexenoate; and 4-Pentenoic acid 2-methyl-, hexyl ester. The different compounds detected in this study that have hexanoic acid-containing moiety may play an important role in the plant's defense system. Studies report that hexanoic acid is a priming inducer that triggers plants defense against fungi (Aranega-Bou et al., 2014; Finiti et al., 2014). For instance, treatment with hexanoic acid helps the plant to regulate oxidative stress caused by plantpathogen interaction. This oxidative stress protection was previously reported in tomato plants infected with Botrytis cinerea (Finiti et al., 2014). The protective property of hexanoic acid was also reported to be effective against Pseudomonas syringae (Vicedo et al., 2009). Similarly, a total of 16 VOCs were detected from tomato plants treated with different concentration of $\mathrm{N}$. These include an alkane (Farnesan), Sesquiterpene (a-Humulene, $\beta$-Caryophyllene, a-Cedrene, Longifolene, a-Copaene, d-Elemene), Alkyl aldehyde (Nonanal), Monoterpene ( $\beta$-Phellandrene, $p$-Cymene, a-terpiene, (+)-4-carene, Myrcene, $\beta$-pinene, $a$-pinene), and Alkyl aldehyde (Heptanal) (Islam et al., 2017). Among these VOCs, the nonanal and p-cymene were also detected in chili plants, however, both were detected on treated and untreated plants.

The green leaf volatiles (GLV) with an increased peak in the $\mathrm{N}$ - treated capsicum plants were 2-Hexenal, 1-Hexanol, and 3-Hexen-1-ol, (Z)-. The detection of the
3-Hexenal, 2-Hexenal, 3-Hexen-1-ol, (Z)- and 2-Hexen-1-ol, (E)- suggest that the GLV synthesis is active in the $\mathrm{N}$-treated plant. The synthesis of GLV begins when galactolipids and phospholipids in the thylakoid membranes are digested with lipase enzymes releasing linoleic acid; the oxidation of a diene catalyzed by the 13-Lipoxygenase produces 13-hydroperoxide, which will then undergo further oxidation to produce (Z)-3-Hexenal or $\mathrm{n}$-Hexenal through isomerization; when treated with aldehyde reductase, aldo/keto reductase or alcohol dehydrogenase 3-Hexen-1-ol, (Z)- and 2-Hexen-1-ol, (E)- can be produced, respectively (Kunishima et al,. 2016). The emission of (Z)-3-Hexen-1-ol in plants can have different functions such as the enhancement of defense against insect pests e.g. the (Z)-3-Hexen-1-ol function to elicit a defense system in tea plants, $\mathrm{Ca}$ mellia sinensis, against the attack by the tea geometrid Ectropis oblique by increasing VOC emission and the activity of polyphenol oxidase. In return, the release of VOCs attracted a parasitoid of the tea geometrid (Xin et al., 2016). The (Z)-3-Hexen-1-ol is also known to attract other beneficial insects, such as Stethorus p. picipes, Orius tristicolor, Anagrus daanei, Syrphidae, Braconidae, and Micro-Hymenoptera (James, 2005). Similarly, the detected 4-Pentenoic acid, 2-methyl-, hexylester, in plant treated with nitrogen, initiates plants' mechanism for insect control (Janzantti et al., 2012; Tewari et al., 2014). On the other hand, the detected hexan-1ol was previously observed to have a repellent effect on Ceutorhynchus assimilis (Smart and Blight, 1997). Nevertheless, the GLVs detected in this study suggest the presence of compounds that establish an insect-plant relationship (Smart and Blight, 1997; James, 2005; Xin et al., 2016; Kunishima et al,. 2016).

In conclusion, excessive concentration of nitrogen weakens the overall plant health making it more susceptible to herbivory and infestation (Islam et al., 2017; Veromann et al., 2013). In this study, we have identified a range of volatiles that may function in defense against a wide array of stresses. The majority of the detected volatiles were pro- 
duced by plants in response to nitrogen-induced insect infestation and the presence of black spots. Although these volatiles have been reported in previous studies, this is the first study that reports their involvement in C. annuum when exposed to increased nitrogen conditions. We believe that the results obtained from this study will contribute in understanding the mechanisms behind volatile emission in C. annuum var. longum in response to $\mathrm{N}$-nutrition. Also, the profile of plant volatiles is useful especially in the field of agriculture to avoid infestation and disease outbreak.

The authors would like to extend their gratitude to the Department of Science and Technology-Science Education Institute Accelerated Science and Technology Human Resource Development Program-National Science Consortium (DOST-SEI ASTHRDP-NSC) for the scholarship and financial assistance.

\section{Literature Cited}

Aliyu, L. 2000. Effect of organic and mineral fertilizers on growth, yield, and composition of pepper (Capsicum annuum L.). Biological Agriculture and Horticulture, 18(1): 29-36.

Anitha, S. and Geethakumari, V.L. 2006. Nutrient management in chilli (Capsicum annuum L.) based cropping system. Indian Journal of Crop Science, 1 (1 and 2): 209-210.

Aranega-Bou, P., de la O Leyva, M., Finiti, I., GarcíaAgustín, P. and González-Bosch, C. 2014. Priming of plant resistance by natural compounds. Hexanoic acid as a model. Frontiers in Plant Science, 5: 488.

Bargavi, R. and Elumalai, S. 2010. In vitro clonal propogation of Capsicum annum L. var.(Arka lohit and Arka suphal) for fruit borer disease resistance. Biosciences, Biotechnology Research Asia, 7(1): 281-8.

Cirlini, M., Luzzini, G., Morini, E., Folloni, S., Ranieri, R., Dall'Asta, C. and Galaverna, G., 2019. Evaluation of the volatile fraction, pungency and extractable color of different Italian Capsicum annuum cultivars designed for food industry. European Food Research and Technology, 245(12): 26692678.

Effah, E., Holopainen, J.K. and McCormick, A.C. 2019. Potential roles of volatile organic compounds in plant competition. Perspectives in Plant Ecology,
Evolution and Systematics, 38: 58-63.

Eggink, P.M., Maliepaard, C., Tikunov, Y., Haanstra, J.P.W., Bovy, A.G. and Visser, R.G.F., 2012b. A taste of sweet pepper: Volatile and non-volatile chemical composition of fresh sweet pepper (Capsicum annuum) in relation to sensory evaluation of taste. Food Chemistry, 132(1): 301-310.

Eggink, P.M., Maliepaard, C., Tikunov, Y., Haanstra, J.P.W., Pohu-Flament, L.M.M., de Wit-Maljaars, S.C., Willeboordse-Vos, F., Bos, S., Benningde Waard, C., De Grauw-van Leeuwen, P.J. and Freymark, G., 2012a. Prediction of sweet pepper (Capsicum annuum) flavor over different harvests. Euphytica, 187(1): 117-131.

Finiti, I., de la O Leyva, M., Vicedo, B., Gómez-Pastor, R., López-Cruz, J., García-Agustín, P., Real, M.D. and González-Bosch, C. 2014. Hexanoic acid protects tomato plants against Botrytis cinerea by priming defense responses and reducing oxidative stress. Molecular Plant Pathology, 15(6): 550-562.

Firdaus, S., Van Heusden, A., Harpenas, A., Supena, E. D., Visser, R.G., and Vosman, B. 2011. Identification of silverleaf whitefly resistance in pepper. Plant Breeding, 130(6): 708-714.

Gaytán, V.G., Merino, F.C., Téllez, L.I., Castillo, G. and Morales, S.G. 2017. The Chilhuacle Chili (Capsicum annuum L.) in Mexico: Description of the Variety, Its Cultivation, and Uses, International Journal of Agronomy, v. 2017, Article ID 5641680

Gou, W., Zheng, P., Tian, L., Gao, M., Zhang, L., Akram, N.A. and Ashraf, M. 2017. Exogenous application of urea and a urease inhibitor improves drought stress tolerance in maize (Zea mays L.). Journal of Plant Research, 130(3): 599-609.

Gouinguené, S.P. and Turlings, T.C. 2002. The effects of abiotic factors on induced volatile emissions in corn plants. Plant Physiology, 129(3): 12961307.

Hansen, U. and Seufert, G. 1999. Terpenoid emission from Citrus sinensis (L.) OSBECK under drought stress. Physics and Chemistry of the Earth, Part B: Hydrology, Oceans and Atmosphere, 24(6): 681687.

Hansen, U. and Seufert, G. 2003. Temperature and light dependence of $\beta$-caryophyllene emission rates. Journal of Geophysical Research: Atmospheres, 108(D24).

Heiser Jr, C.B., and Pickersgill, B. 1969. Names for the Cultivated Capsicum Species (Solanaceae). Taxon, 18 (3): 277-283.

Hiltpold, I., Toepfer, S., Kuhlmann, U. and Turlings, T.C. 2010. How maize root volatiles affect the efficacy of entomopathogenic nematodes in controlling the western corn rootworm? Chemoecology, 20(2): 155-162.

Holopainen, J.K., and Gershenzon, J. 2010. Multiple stress factors and the emission of plant VOCs. Trends in Plant Science, 15(3): 176-184. 
Islam, M., Saha, S., Akand, H. and Rahim, A. 2011. Effect of spacing on the growth and yield of sweet pepper (Capsicum annuum L.). Journal of Central European Agriculture, 12(2): 328-335.

Islam, M.N., Hasanuzzaman, A.T.M., Zhang, Z.F., Zhang, Y. and Liu, T.X. 2017. High Level of Nitrogen Makes Tomato Plants Releasing Less Volatiles and Attracting More Bemisia tabaci (Hemiptera: Aleyrodidae). Frontiers in Plant Science, 8: 466.

James, D. G. 2005. Further field evaluation of synthetic herbivore-induced plan volatiles as attractants for beneficial insects. Journal of Chemical Ecology, 31(3): 481-495.

Jansson, R. K., and Smilowitz, Z. 1986. Influence of nitrogen on population parameters of potato insects: abundance, population growth, and within-plant distribution of the green peach aphid, Myzus persicae (Homoptera: Aphididae). Environmental Entomology, 15(1): 49-55.

Janzantti, N., Macoris, M., Garruti, D. and Monteiro, M. 2012. Influence of the cultivation system in the aroma of the volatile compounds and total antioxidant activity of passion fruit, LWT - Food Science and Technology, 46: 511-518

Jassbi, A.R., Zamanizadehnajari, S. and Baldwin, I.T. 2010 Phytotoxic volatiles in the roots and shoots of Artemisia tridentata as detected by headspace solid-phase microextraction and gas chromatographic-mass spectrometry analysis. Journal of Chemical Ecology, 36(12): 1398-1407.

Jauset, A.M., Sarasua, M.J., Avilla, J., and Albajes, R. 1998. The impact of nitrogen fertilization of tomato on feeding site selection and oviposition by Trialeurodes vaporariorum. Entomologia Experimentalis et Applicata, 86(2): 175-182.

Kirstine, W.V. and Galbally, I.E. 2004. A Simple Model for Estimating Emissions of Volatile Organic Compounds from Grass and Cut Grass in Urban Airsheds and Its Application to Two Australian Cities, Journal of the Air and Waste Management Association, 54(10): 1299-1311.

Kirstine, W.V., Galbally, I.E., Ye, Y. and Hooper, M. 1998. Emissions of volatile organic compounds (primarily oxygenated species) from pasture, Journal of Geophysical Research, 103: 1060510619.

Kreuzwieser, J., Scheerer, U., Kruse, J., Burzlaff, T., Honsel, A., Alfarraj, S., Georgiev, P., Schnitzler, J.P., Ghirardo, A., Kreuzer, I. and Hedrich, R. 2014. The Venus flytrap attracts insects by the release of volatile organic compounds. Journal of Experimental Botany, 65(2): 755-766.

Kunishima, M., Yamauchi, Y., Mizutani, M., Kuse, M., Takikawa, H. and Sugimoto, Y. 2016. Identification of (Z)-3:(E)-2-hexenal isomerases essential to the production of the leaf aldehyde in plants. Journal of Biological Chemistry, 291(27): 1402314033.
Lou, Y. and Baldwin, I.T. 2004. Nitrogen supply influences herbivore-induced direct and indirect defenses and transcriptional responses in Nicotiana attenuata. Plant Physiology, 135(1): 496-506.

Lu, Z.X., Yu, X.P., Heong, K.L., and Cui, H.U. 2007. Effect of nitrogen fertilizer on herbivores and its stimulation to major insect pests in rice. Rice Science, 14(1): 56-66.

Maleknia, S.D., Vail, T.M., Cody, R.B., Sparkman, D.O., Bell, T.L. and Adams, M.A., 2009. Temperaturedependent release of volatile organic compounds of eucalypts by direct analysis in real time (DART) mass spectrometry. Rapid Communications in Mass Spectrometry: An International Journal Devoted to the Rapid Dissemination of Up-to-the-Minute Research in Mass Spectrometry, 23(15): 2241-2246.

McBride, M.F. 2016. Extraction of resins from Capsicum annuum var. longum (Siling haba) for the study of their potential anti-microbial activities. Journal of Chemical and Pharmaceutical Research, 8(3): 117-127.

Molla, T., Abera, G. and Beyene, S. 2019. Effects of Nitrogen Fertilizer and Mulch Application on Growth Performance and Pod Yields of Hot Pepper (Capsicum annuum L.) under Irrigated Condition. International Journal of Plant and Soil Science, 27(5): 1-15.

Moreau, D., Pivato, B., Bru, D., Busset, H., Deau, F., Faivre, C., Matejicek, A., Strbik, F., Philippot, L. and Mougel, C. 2015. Plant traits related to nitrogen uptake influence plant-microbe competition. Ecology, 96(8): 2300-2310.

Perera, R.M., Marriott, P.J., Galbally, I.E. 2002. Headspace solid-phase microextraction-Comprehensive two-dimensional gas chromatography of wound induced plant volatile organic compound emissions. Analyst, 127(12): 1601-1607.

Redillas, M.C.F.R., Jeong, J.S., Strasser, R.J., Kim, Y.S., and Kim, J.K. 2011. JIP analysis on rice (Oryza sativa cv Nipponbare) grown under limited nitrogen conditions. Journal of the Korean Society for Applied Biological Chemistry, 54(5): 827-832.

Saad, K.A., Roff, M.M., Hallett, R.H., and Idris, A.B. 2015. Aphid-induced defences in chilli affect preferences of the whitefly, Bemisia tabaci (Hemiptera: Aleyrodidae). Scientific Reports, 5(1): 1-9.

Salas, R.A., Gonzaga, Z.C., Wu, D.L., Luther, G., Gniffke, P.A., and Palada, M.C. 2015. Effects of physical barrier and insect growth regulator on whitefly control and yield of chili pepper (Capsicum annuum L.). Journal of Food and Nutrition Sciences, 3(1-2): 13-19.

Salerno, G., Frati, F., Marino, G., Ederli, L., Pasqualini, S., Loreto, F., Colazza, S. and Centritto, M. 2017. Effects of water stress on emission of volatile organic compounds by Vicia faba, and consequences for attraction of the egg parasitoid 
Trissolcus basalis. Journal of Pest Science, 90(2): 635-647.

Samburova, V., McDaniel, M., Campbell, D., Wolf, M., Stockwell, W.R. and Khlystov, A. 2019. Dominant volatile organic compounds (VOCs) measured at four Cannabis growing facilities: pilot study results. Journal of the Air and Waste Management Association, 69(11): 1267-1276.

Sharma, R. and Kumar, R. 2017. Growth, flowering and yield of chilli,(Capsicum annuum L.) as influenced by spacing and growing conditions. Indian Journal of Pure and Applied Biosciences, 5(5): 524-527.

Silva, É.A.S., Saboia, G., Jorge, N.C., Hoffmann, C., dos Santos Isaias, R.M., Soares, G.L. and Zini, C.A. 2017. Development of a HS-SPME-GC/MS protocol assisted by chemometric tools to study herbivore-induced volatiles in Myrcia splendens. Talanta, 175: 9-20.

Silva, L.R., Azevedo, J., Pereira, M.J., Valentão, P. and Andrade, P.B. 2013. Chemical assessment and antioxidant capacity of pepper (Capsicum annuum L.) seeds. Food and Chemical Toxicology, 53: 240-248.

Smart, L.E., and Blight, M.M. 1997. Field discrimination of oilseed rape, Brassica napus volatiles by cabbage seed weevil, Ceutorhynchus assimilis. Journal of Chemical Ecology, 23(11): 2555-2567.

Spinelli, F., Cellini, A., Marchetti, L., Nagesh, K.M. and Piovence, C. 2011. Emission and Function of Volatile Organic Compounds in Response to Abiotic Stress. Department of Fruit Tree and Woody Plant Sciences, 16: 367-393.

Tálaga-Taquinas, W., Melo-Cerón, C. I., Lagos-Álvarez, Y. B., Duque-Gamboa, D. N., Toro-Perea, N. and Manzano, M. R. 2020. Identification and life history of aphids associated with chili pepper crops in southwestern Colombia. Universitas Scientiarum, 25(2): 175-200.

Tavera, M.A.A., Lago, J.C.A., Magalong, V.K.D., Vidamo, G.A.V., Carandang, J.S.R., Amalin, D.M., Janairo, J.I.B. 2018. Effect of Aspidiotus rigidus infestation on the volatile chemical profile of the host plant Garcinia mangostana. Hellenic Plant Protection Journal, 11(1): 1-8.

Teuber, M., Zimmer, I., Kreuzwieser, J., Ache, P., Polle, A., Rennenberg, H. and Schnitzler, J.P. 2008. VOC emissions of Grey poplar leaves as affected by salt stress and different $\mathrm{N}$ sources. Plant Biology, 10(1): 86-96.

Tewari, S., Leskey, T.C., Nielsen, A.L., Piñero, J.C., and Rodriguez-Saona, C.R. 2014. Use of pheromones in insect pest management, with special attention to weevil pheromones. In Integrated Pest Management (pp. 141-168). Academic Press.
Veromann, E., Toome, M., Kännaste, A., Kaasik, R., Copolovici, L., Flink, J., Kovács, G., Narits, L., Luik, A. and Niinemets, Ü. 2013. Effects of nitrogen fertilization on insect pests, their parasitoids, plant diseases and volatile organic compounds in Brassica napus. Crop Protection. 43: 79-88.

Vicedo, B., Flors, V., de la O Leyva, M., Finiti, I., Kravchuk, Z., Real, M.D., García-Agustín, P. and González-Bosch, C. 2009. Hexanoic acid-induced resistance against Botrytis cinerea in tomato plants. Molecular Plant-Microbe Interactions, 22(11):1455-1465.

Vuorinen, T., Nerg, A.M., Holopainen, J.K. 2004. Ozone exposure triggers the emission of herbivore-induced plant volatiles, but does not disturb tritrophic signalling. Environmental Pollution, 131(2): 305-311.

Wahocho, N.A., Zeshan Ahmed, S., Jogi, Q., Talpur, K.H. and Leghari, S.J. 2016. Growth and productivity of chilli (Capsicum annuum I.) under various nitrogen levels. Science International, 28(2): 1321-1326.

Walsh, B.M. and Hoot, S.B. 2001. Phylogenetic Relationships of Capsicum (Solanaceae) Using DNA Sequences from Two Noncoding Regions: The Chloroplast atpB-rbcL Spacer Region and Nuclear waxy Introns. International Journal of Plant Sciences, 162(6): 1409-1418.

Xin, Z., Li, X., Li, J., Chen, Z. and Sun, X. 2016 Application of chemical elicitor (Z)-3-hexenol enhances direct and indirect plant defenses against tea geometrid Ectropis obliqua. BioControl, 61(1): $1-12$.

Zhigila, D.A., Abdul Rahaman, A.A., Kolawole, O.S. and Oladele, F. 2014. Fruit Morphology as Taxonomic Features in Five Varieties of Capsicum annuum L. Solanaceae, Journal of Botany, v. 2014, Article ID 540868.

Ziino, M., Condurso, C., Romeo, V., Tripodi, G. and Verzera, A. 2009. Volatile compounds and capsaicinoid content of fresh hot peppers (Capsicum annuum L.) of different Calabrian varieties. Journal of the Science of Food and Agriculture, 89(5): 774-780.

Received: 25 May 2020; Accepted: 27 April 2021 


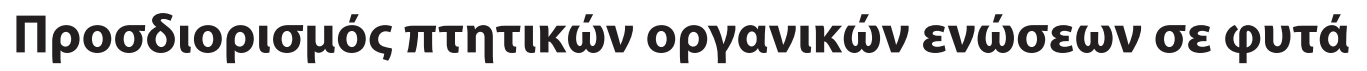

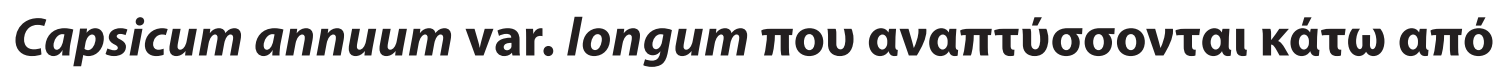

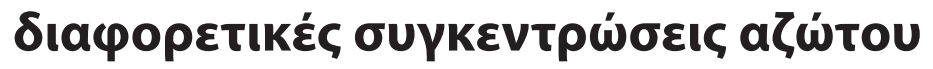

\author{
Y.C. David, J.B. Ylagan, H.A. Gonzales, J.M.P. Chan, J.M.S. Mondragon, \\ M.A.A. Tavera and M.C.F.R. Redillas
}

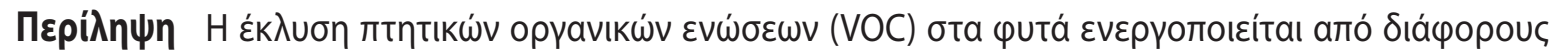

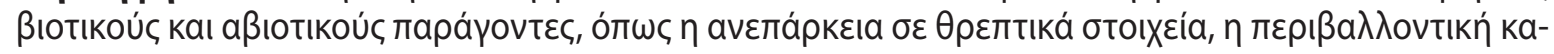

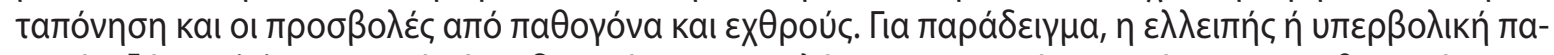

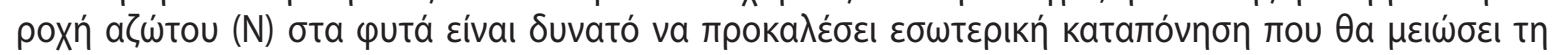

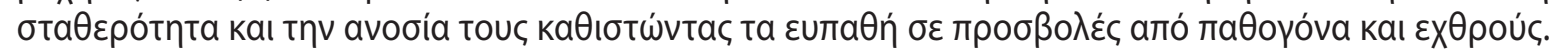

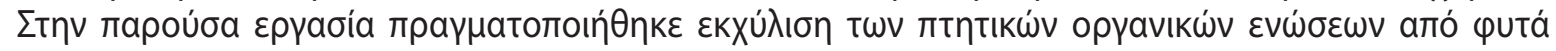

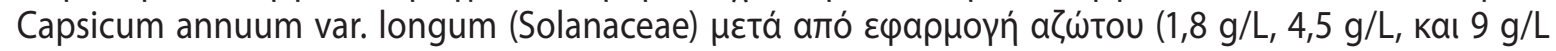

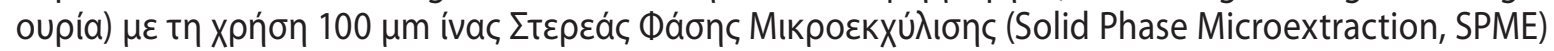

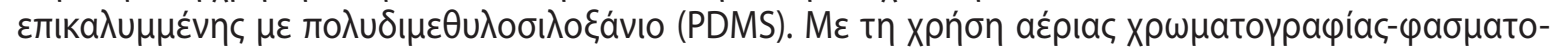

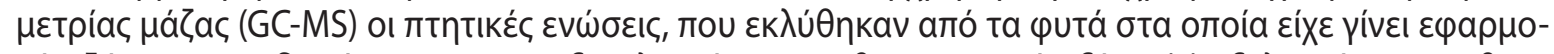

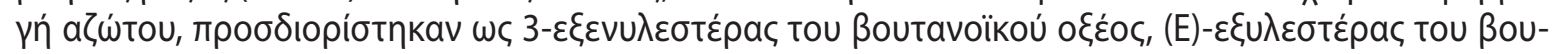

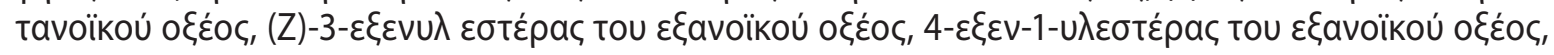

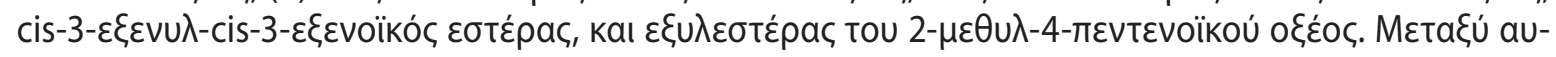

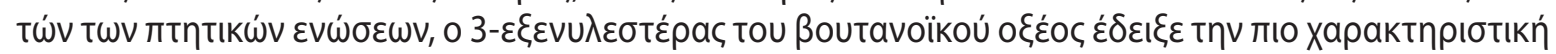

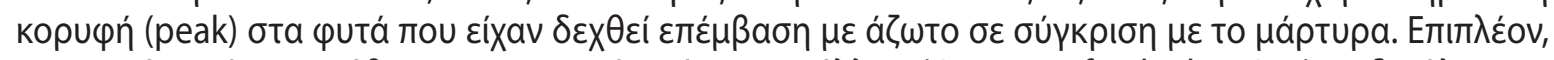

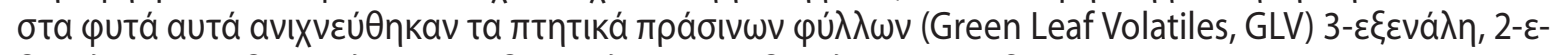

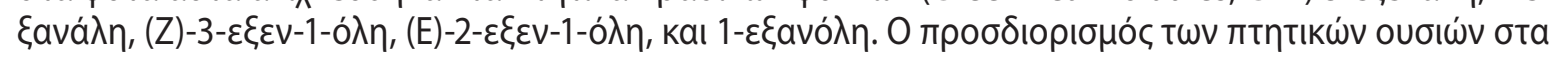

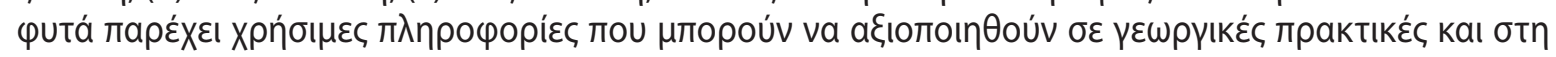

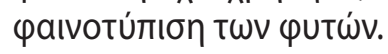

Hellenic Plant Protection Journal 14: 77-88, 2021 